\title{
Effect of temperature, salinity, light and time of dehiscence on seed germination and seedling morphology of Calotropis procera from urban habitats
}

\author{
Tarek M. Galal ${ }^{\star}$, Emad A. Farahat, Maha M. El-Midany and Loutfy M. Hassan \\ Botany and Microbiology Department, Faculty of Science, Helwan University, Cairo, Egypt.
}

Received 6 November, 2014; Accepted 27 March, 2015

\begin{abstract}
Calotropis procera (giant milkweed) is a hardy xerophytic plant, which is distributed globally in many countries and has important economic and ecological functions. The present study aimed at estimating the effect of temperature, salinity and time of fruit dehiscence on the seed germination and seedling morphology of giant milkweed in urban habitats. Seeds were collected early (in June) and late (in December) from pre-dehiscent (EPRD, LPRD) and post-dehiscent (EPOD, LPOD) fruits. Mature seeds were $100 \%$ viable, while premature seeds did not germinate. The highest germination and mean time to germination was attained in full dark followed by dark/light, while no germination occurred at complete light. A significant difference between seeds from pre- and post-dehiscent fruits was assessed, while no significant difference between early and late seeds. Maximum germination was at 25 and $30^{\circ} \mathrm{C}$, while germination was inhibited at $35^{\circ} \mathrm{C}$, which demonstrates that temperature is one of the critical factors for giant milkweed seed germination. Moreover, salinity more than $2000 \mathrm{~g} \mathrm{I}^{-1} \mathrm{NaCl}$ inhibited seed germination. It is likely that high temperature, direct light conditions and high salinity are the limiting factors for the establishment of giant milkweed seeds. The germination of $C$. procera seeds was significantly affected when germinated with Trigonella foenum-vulgare with the reduction of germination from 100 to $34 \%$, while the later plant was not affected. C. procera is considered as an important medicinal plant; therefore, our results provide useful information for its management under different environmental conditions.
\end{abstract}

Key words: Giant milkweed, seed morphology, fruit dehiscence, germination time and viability.

\section{INTRODUCTION}

Germination requirements and dormancy characteristics of species are often assumed to be adaptations to the particular habitat, where the species occur (Angevine and Chabot, 1979; Meyer et al., 1990). Germination at the right

${ }^{*}$ Corresponding author. E-mail: tarekhelwan@yahoo.com. Tel: 00201270751494.

Abbreviations: EPRD, Early pre-dehiscent; EPOD, early post-dehiscent; LPRD, late pre-dehiscent; LPOD, late post-dehiscent.

Author(s) agree that this article remains permanently open access under the terms of the Creative Commons Attribution License 4.0 International License 
time and in the right place is important to determine the probability of a seedling surviving to maturity (Thompson, 1973). Seed germination and early seedling growth are critical stages for the establishment of plant populations under saline conditions (Perez et al., 1998; Khan and Gulzar, 2003). Salinity and temperature have differential effects on seed germination (Khan and Gulzar, 2003, AlKhateeb, 2006). In temperate regions, many plant species have evolved physiological mechanisms in the seeds to detect the appropriate time for germination (Washitani and Masuda, 1990; Baskin and Baskin, 1998). Ecophysiological studies of seed germination have suggested that temperature, its changes, and its fluctuation can be the most reliable environmental signals to indicate the appropriate timing for germination (Baskin and Baskin, 1998).

Calotropis procera (Asclepiadaceae) is a perennial shrub that primarily reproduces via seeds. It is native to tropical and subtropical Africa and Asia, and common in the Middle East (Parsons and Cuthbertson, 2001; Lottermoser, 2011). C. procera (also known as Sodom apple, giant milkweed, cabbage tree and rubber tree) is a xerophytic shrub or small tree. It grows as a wasteland weed and flowers and fruits profusely every year from March to May. This plant can tolerate adverse climatic conditions and poor soils. It has an evergreen behavior under field conditions, from young plant to the reproductive stage (Frosi et al., 2012). The fruit dehisces along the ventral suture at maturity while still green dispersing on an average of $230 \pm 19$ silky haired seeds (Lottermoser, 2011). C. procera is well known to attract/support about 80 animal species ranging from casual visitors to those fully dependent on the plant for completion of their life cycle (Sharma and Amritphale, 2008; Boutraa, 2010). It had been widely used in traditional medicine due to its pharmacological active compounds found in all plant parts; barks, roots, leaves and especially its milky latex which exudates from damaged and broken leaves and stems (Magalhaes et al., 2010). A wide range of chemical compounds have been isolated from giant milkweed, including cardiac glycosides, flavonoids, phenolic compounds, terpenoides (Mueen Ahmed et al., 2005). Because of these active chemical compounds, C. procera has been used for treatment of a number of diseases, such as ulcers, tumors, leprosy, piles and diseases of the spleen, liver and abdomen. Furthermore, C. procera is optionally used for animal feed during dry periods in the semi-arid regions (Boutraa, 2010).

Rarity of endangered plant species can be strongly related to human threats and environmental limiting factors, and understanding of these factors is a necessity to protect the vegetation of these plant species. Further climate change with high temperature associated with dry conditions might be an important factor in reducing the success of regeneration of a number of plant species. Another factor that can greatly affect plant diversity is the herbivore grazing (Wei et al., 2009). Few studies were carried out on the seed germination of $C$. procera (Sen et al., 1968; Sharma and Amritphale, 2008). Some studies were conducted under controlled (Boutraa, 2010) or field conditions from ecological and ecophysiological perspectives (Khan et al., 2007; Oliveira et al., 2009; Tezara et al., 2011). To provide basic information for its conservation and restoration in natural and urban habitats, we studied the influence of environmental factors on seed germination patterns. The germination responses of seeds as well as seedling growth were determined over a wide range of temperatures, light intensity and salinity gradients. In addition, the effect of the time of fruit dehiscence on the seed germination of $C$. procera was also tested. A bioassay test was conducted to investigate the effect of giant milkweed seed germination on the germination of economic plants seeds.

\section{MATERIALS AND METHODS}

\section{Seed collection}

Mature and premature seeds, from post-dehiscent and pre-dehiscent fruits, respectively, of $C$. procera were collected during June (early) and December (late) 2012, from several plants belonging to different populations which are naturally growing in the urban habitats in Helwan region, Cairo, Egypt. Seeds were collected from predehiscent (manually opened) and post-dehiscent (naturally opened) fruits. Fruits and seeds characteristics such as length, width and weight as well as number of seeds per fruit were measured. After removing the seed silky hairs, which had little effect on seed germination in the preliminary studies (Sharma and Amritphale, 2008), the seeds were allowed to desiccate in paper bags for three days at room temperature, washed twice with distilled water, and then stored at room temperature in dry and dark conditions after sterilization with $0.5 \%$ sodium hypochlorite solution for $1 \mathrm{~min}$.

\section{Viability test, light, temperature and salinity experiment}

The viability of premature and mature seed was tested by 2,3,5triphenyltetrazolium chloride (TZ) method (ISTA, 1985). To determine the optimal light requirements for seed germination, 15 seeds (three replicates) were placed in sterilized $9 \mathrm{~cm}$ Petri dishes containing two layers of filter papers moistened with distilled water, and incubated at $25^{\circ} \mathrm{C}$ at full light, equal light: dark and full dark. Light intensity was 1985 lux (PPFD $=26.8 \mu \mathrm{mol} \mathrm{m} \mathrm{m}^{-2} \mathrm{~s}^{-1}$ ). The effect of temperature on seed germination was tested in sterilized Petri dishes, where a set of 15 seeds (five replicates) was subjected to the following temperatures: $15,20,25,30$ and $35^{\circ} \mathrm{C}$ in dark (optimum conditions). For each treatment, seeds were gathered from early pre-dehiscent (EPRD), early post-dehiscent (EPOD), late predehiscent (LPRD) and late post-dehiscent (LPOD) fruits. For studying the effect of salinity on seed germination, another set of 15 seeds (five replicates) was placed in Petri dishes containing two layers of filter paper at different concentrations of $\mathrm{NaCl}(500,1000$, 2000,3000 and $4000 \mathrm{mg} \mathrm{l}^{-1}$ ) and incubated at $25^{\circ} \mathrm{C}$ in dark (optimum conditions). For each treatment, growth parameters (shoot and root length) were recorded at the last day of the germination experiments. The seed was considered to have germinated when the radical emerged from the seed coat. Germination was monitored until no more new seed germination was observed over seven consecutive days. 
Table 1. Light requirements for germination and mean time to germination (MTG) of Calotropis procera seeds.

\begin{tabular}{lcc}
\hline $\begin{array}{l}\text { Variable } \\
\text { (light treatment) }\end{array}$ & Germination (\%) & MTG (days) \\
\hline Light & $0^{\mathrm{a}}$ & $0^{\mathrm{a}}$ \\
Light / dark & $82.7 \pm 2.9^{\mathrm{b}}$ & $18.7 \pm 3.9^{\mathrm{b}}$ \\
Dark & $98.7 \pm 16.7^{\mathrm{c}}$ & $24.1 \pm 0.5^{\mathrm{c}}$ \\
\hline
\end{tabular}

Values are mean $\pm S D(n=3)$. Different letters within a column indicate that means are significantly different among light treatments $(p<0.05)$.

Table 2. Germination and mean time to germination (MTG) of Calotropis procera seeds at different temperature treatments.

\begin{tabular}{|c|c|c|c|c|c|}
\hline Temperature $\left({ }^{\circ} \mathrm{C}\right)$ & EPOD & EPRD & LPOD & LPRD & F-value \\
\hline \multicolumn{6}{|l|}{ Germination (\%) } \\
\hline 20 & $0^{\mathrm{a}}$ & $1.3 \pm 2.9^{a}$ & $54.7 \pm 27.6^{\mathrm{a}}$ & $22.7 \pm 12.1^{\mathrm{a}}$ & $14.2^{* *}$ \\
\hline 25 & $96.4 \pm 7.6^{\mathrm{b}}$ & $22.7 \pm 18.0^{b}$ & $93.3 \pm 8.2^{\mathrm{b}}$ & $50.7 \pm 23.9^{b d}$ & $27.0^{\star \star}$ \\
\hline 30 & $80.0 \pm 19.4^{c}$ & $49.3 \pm 12.9^{c}$ & $85.3 \pm 20.2^{b}$ & $61.3 \pm 15.9^{b c}$ & $4.6^{\star}$ \\
\hline 35 & $65.3 \pm 15.2^{d}$ & $6.7 \pm 6.7^{\mathrm{a}}$ & $80.0 \pm 21.1^{\mathrm{ab}}$ & $33.3 \pm 10.5^{\mathrm{ad}}$ & $25.9^{* \star}$ \\
\hline \multicolumn{6}{|l|}{ MTG (days) } \\
\hline 20 & $0^{\mathrm{a}}$ & $0.1 \pm 0.2^{\mathrm{a}}$ & $6.9 \pm 3.2^{\mathrm{a}}$ & $2.5 \pm 1.3^{\mathrm{a}}$ & $18.0^{\star *}$ \\
\hline 25 & $22.1 \pm 2.2^{b}$ & $2.6 \pm 2.5^{\mathrm{a}}$ & $22.8 \pm 2.5^{\mathrm{b}}$ & $12.1 \pm 5.7^{\mathrm{bd}}$ & $35.8^{* *}$ \\
\hline 30 & $19.0 \pm 5.1^{\mathrm{bc}}$ & $19.9 \pm 25.9^{b}$ & $20.9 \pm 5.4^{b}$ & $14.5 \pm 4.5^{\mathrm{bc}}$ & 0.2 \\
\hline 35 & $15.9 \pm 3.7^{c}$ & $0.8 \pm 0.7^{\mathrm{a}}$ & $19.1 \pm 5.5^{b}$ & $7.3 \pm 2.9^{\mathrm{ad}}$ & $26.4^{\star \star}$ \\
\hline
\end{tabular}

EPRD: Early pre-dehiscent, EPOD: early post-dehiscent, LPRD: late pre-dehiscent and LPOD: late post-dehiscent fruits. Values are mean $\pm S D(n=3)$. Different letters within a column indicate that means are significantly different among temperature treatments. ${ }^{*}: \mathrm{P}<0.01$ and ${ }^{* *}: \mathrm{P}<0.001$.

\section{Bioassay test}

A bioassay test was conducted to estimate the effect of germinating Calotropis seeds altogether with seeds from another economic plant (Trigonella foenum-vulgare) at $25^{\circ} \mathrm{C}$ using five replicates (10 seeds for each species). Growth parameters (shoot and root length) were recorded at the last day of the germination experiments.

\section{Data analysis}

The mean time to germination (MTG) was calculated as: $\mathrm{MTG}=$ $\frac{\sum(\text { nix di) }}{N}$, Where, ni is the number of seeds germinated at day $i(d i)$, and $\mathrm{N}$ is the total number of seeds germinating in the treatment (Redondo-GÓmez et al., 2008). After testing the data for normality, the differences in the germination percentage, MTG as well as growth variables among the different treatments were tested using one-way analysis of variance (ANOVA) using SPSS software (SPSS, 2006). A post-hoc test was applied when treatment effects were significant.

\section{RESULTS}

The giant milkweed's fruits were more or less rectangular in shape with a mean length of $12 \mathrm{~cm}$ and a mean width of $10 \mathrm{~cm}$. In addition, the fruit weighted about $40 \mathrm{~g}$. Moreover, each fruit could produce about 410 seeds with a mean seed length of $6.6 \mathrm{~mm}$ and width of $4.5 \mathrm{~mm}$, while the weight of 10 seeds was about $0.1 \mathrm{~g}$. Seed viability test indicated a $100 \%$ germination of $C$. procera mature seeds, while premature seeds did not germinate. Seed germination varied significantly according to their light requirements (Table 1). The highest seed germination (98.7\%) and mean time to germination (MTG $=24.1$ days) was obtained at dark conditions, while no germination occurred at full light treatments. The study of $C$. procera seed germination at different temperature treatments indicated significant variation between the different seeds, while mean time to germination was significant different at all temperatures, except at $30^{\circ} \mathrm{C}$ (Table 2). C. procera seeds from EPOD fruits had significant higher germination percentage (96.4\%) at $25^{\circ} \mathrm{C}$, while those from LPOD had no significant differences between 25 and $30^{\circ} \mathrm{C}(93.3$ and $85.3 \%$, respectively). On the other hand, germination of EPRD and LPRD seeds were significantly affected $(p<0.05)$ by temperature variation with the highest germination percentage at $30^{\circ} \mathrm{C}$. Moreover, no germination occurred at $15^{\circ} \mathrm{C}$ for all seeds, while the highest temperature $\left(35^{\circ} \mathrm{C}\right)$ showed notable reduction in the seed germination. 
$20{ }^{\circ} \mathrm{C}$

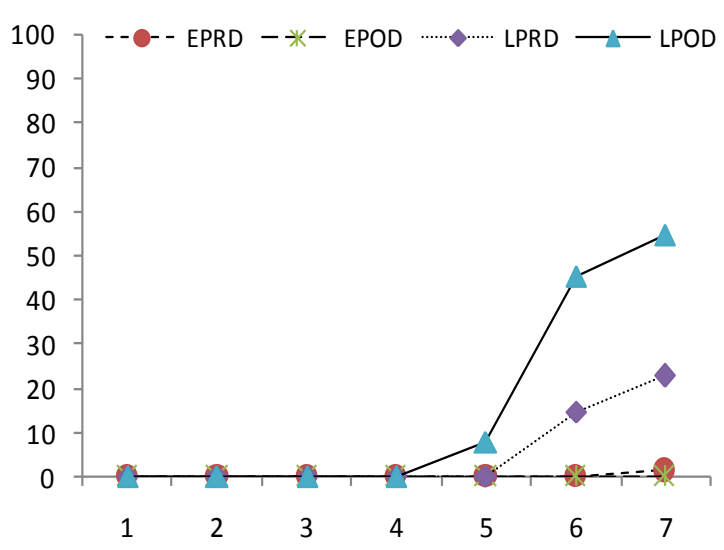

$30{ }^{\circ} \mathrm{C}$

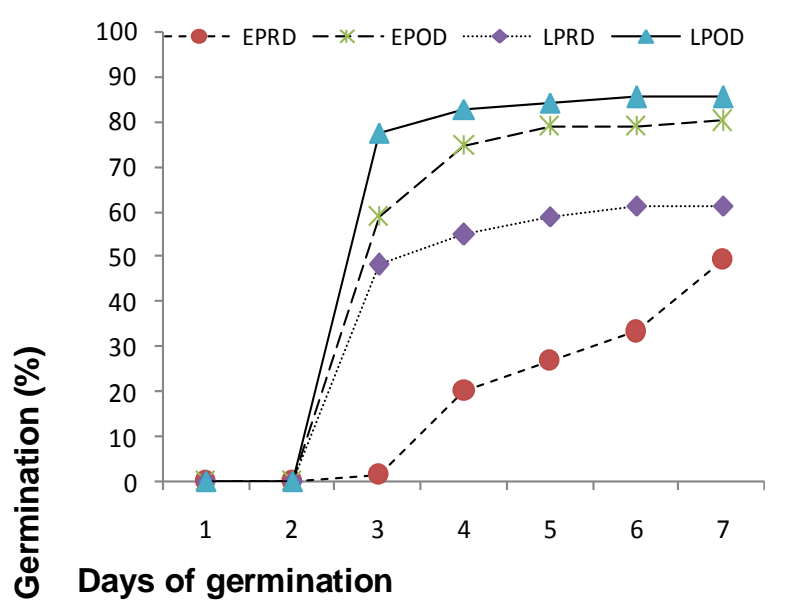

$25^{\circ} \mathrm{C}$

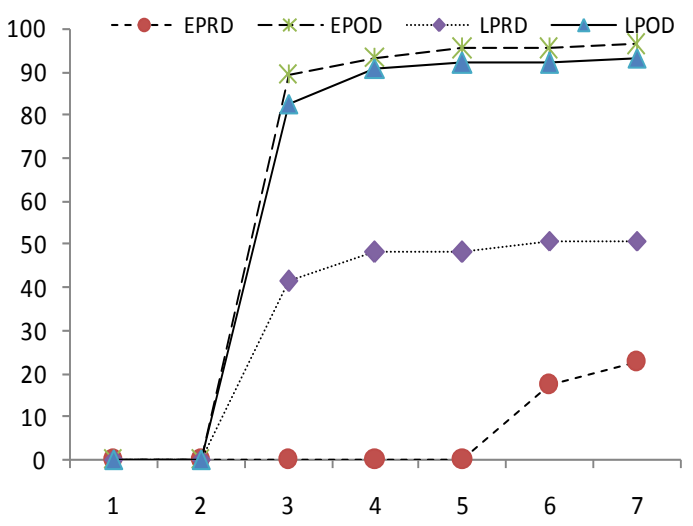

$35{ }^{\circ} \mathrm{C}$

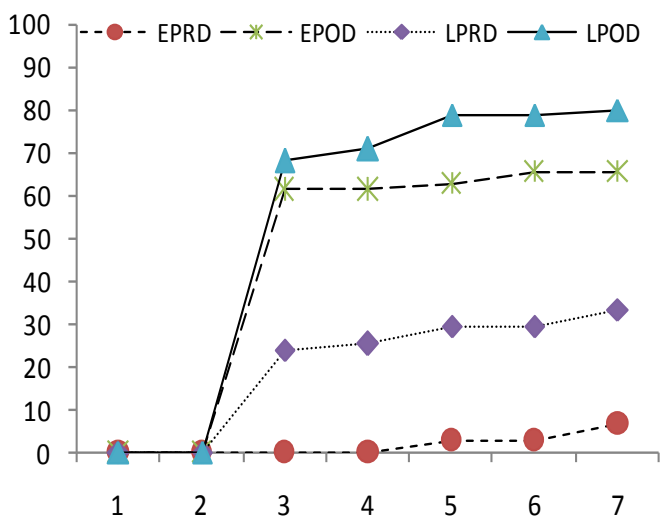

Figure 1. Cumulative mean germination percentage of Calotropis procera seeds collected from different fruits at different maturity stages. EPRD: Early pre-dehiscent, EPOD: early post-dehiscent, LPRD: late pre-dehiscent and LPOD: late postdehiscent fruits.

EPOD and LPOD seeds had significantly the longest MTG at $25^{\circ} \mathrm{C}\left(22.1\right.$ and 22.8 , respectively) and $30^{\circ} \mathrm{C}$ (19.0 and 20.9) with no significant difference between them. All seeds, except EPRD, germinated considerably at the third day of incubation at 25,30 and $35^{\circ} \mathrm{C}$ (Figure 1). At these temperature treatments, the seed germination (\%) was in the order: EPOD > LPOD > LPRD $>$ EPRD. Temperature variation significantly affected the shoot and root lengths of the germinated seedlings (Figure 2). The maximum growth of $C$. procera seedlings after seven days was found at $30^{\circ} \mathrm{C}$, with no significant difference between shoot length of EPRD, LPRD and LPOD, but shoots of EPOD were significantly shorter.

In addition, the longest root was obtained at $30^{\circ} \mathrm{C}$, where LPOD had significantly the longest. Decreasing temperature significantly decreased the shoot and root lengths of $C$. procera seedlings. Percentages of seed germination at different concentrations of $\mathrm{NaCl}$ after seven days of incubation were not significantly different between $\mathrm{NaCl}$ concentrations of 500, 1000 and $2000 \mathrm{mg}$ $\mathrm{I}^{-1}$ and Control (Table 3). Conversely, seed germination at $\mathrm{NaCl}$ concentrations of 3000 and $4000 \mathrm{mg} \mathrm{I}^{-1}$ was significantly lower than at the lower concentrations. It is apparent that at $500 \mathrm{mg} \mathrm{l}^{-1}$ and $1000 \mathrm{mg} \mathrm{l}^{-1} \mathrm{NaCl}$ concentrations, the fastest germination was obtained, $\mathrm{MTG}=$ 24.1 and 24.2, respectively, whereas germination at 3000 and $4000 \mathrm{mg} \mathrm{l}^{-1}$ was significantly retarded. The shoot length of $C$. procera seedlings, after seven days of incubation, is not greatly affected by salinity variations (Table 3). The shoot length at $500 \mathrm{mg} \mathrm{I}^{-1} \mathrm{NaCl}$ was significantly lower compared to the other salinity treatments that had no significant differences between them. On the other hand, the root length of $C$. procera seedlings was significantly decreased by increasing $\mathrm{NaCl}$ concentrations.

The germination of $C$. procera seeds was significantly 

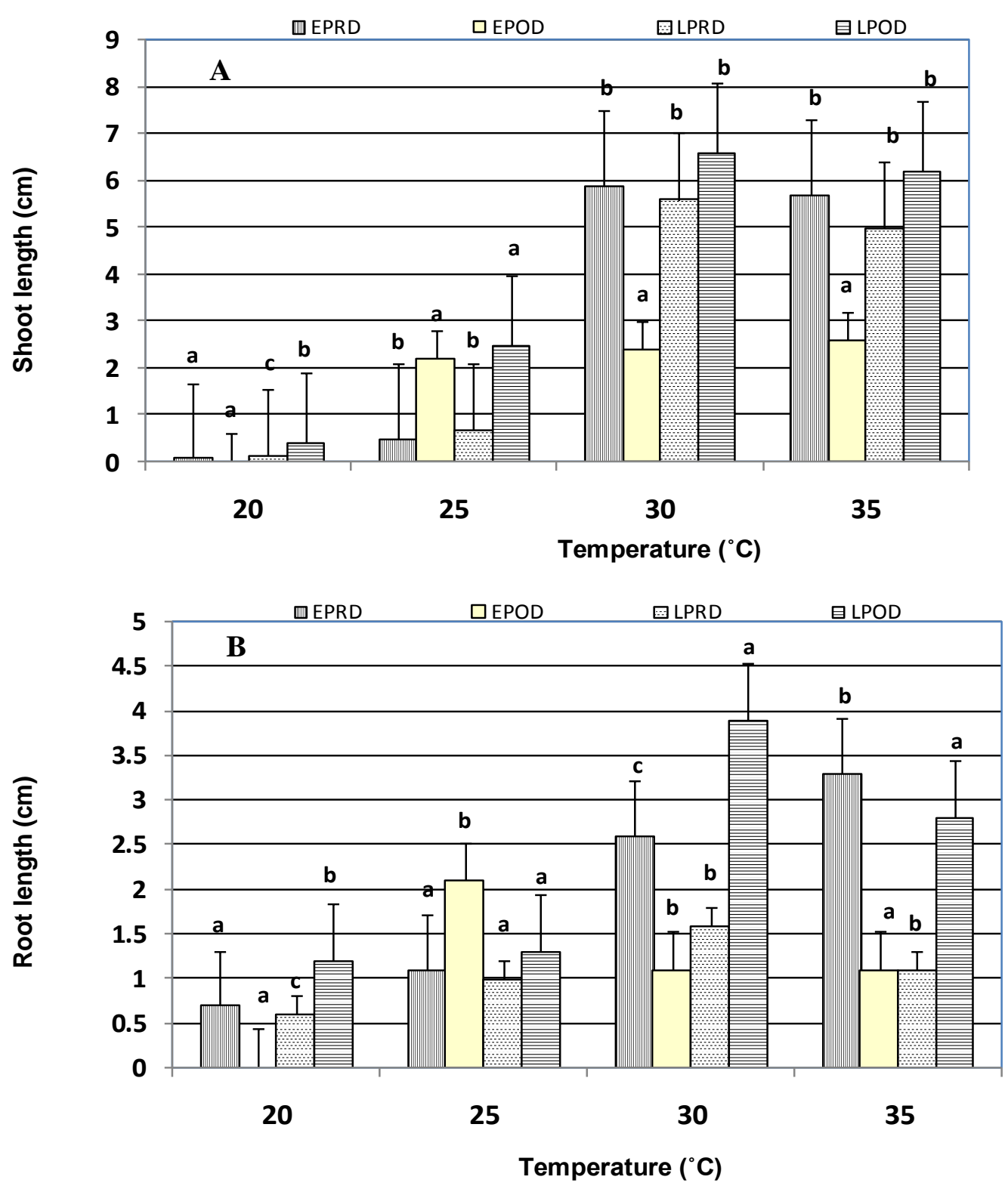

Figure 2. Shoot $(A)$ and root (B) lengths of Calotropis procera seedling after 7 days of seed germination at different temperatures. Lines over bars represent SE. EPRD: Early pre-dehiscent, EPOD: early post-dehiscent, LPRD: late pre-dehiscent and LPOD: late post-dehiscent fruits.

affected when germinated with $T$. foenum-vulgare with the reduction of germination from 100 to $34 \%$, while the later plant was not affected (Table 4). On the other hand, the shoot length of Calotropis and Trigonella seedlings was significantly larger in combination than if each species are alone. Moreover, the root length of both species was not significantly affected.

\section{DISCUSSION}

An increase in atmospheric temperature, particularly in tropical regions, appears to be an inevitable consequence of global climate change. This is likely to affect plant diversity and performance, owing to the relationship between temperature and seed germination, and temperature and plant vigor (Perumal et al., 2014). Seed germination of xerophytes is regulated by factors such as water, temperature, light, soil salinity and their interactions (Noe and Zedler, 2000); however, each species responds to the abiotic environment in a unique manner (Khan and Gulzar, 2003). Due to the importance of $C$. procera in medicine, pharmacology and environment; documentation of its seed germination and effects of different climatic conditions on growth performance and other physiological and biochemical aspects are encouraged 
Table 3. Effect of salinity on germination, mean time to germination (MTG) and seedling growth of Calotropis procera seeds.

\begin{tabular}{ccccc}
\hline NaCl treatment $\left(\mathbf{m g ~ l}^{-1}\right)$ & Germination (\%) & MTG (days) & Shoot length (cm) & root length (cm) \\
\hline 0 & $98.7 \pm 8.0^{\mathrm{a}}$ & $22.7 \pm 3.2^{\mathrm{a}}$ & $3.1 \pm 0.4^{\mathrm{a}}$ & $2.0 \pm 0.5^{\mathrm{a}}$ \\
500 & $100 \pm 0.0^{\mathrm{a}}$ & $24.1 \pm 0.5^{\mathrm{a}}$ & $2.2 \pm 0.4^{\mathrm{b}}$ & $1.4 \pm 0.3^{\mathrm{b}}$ \\
1000 & $100 \pm 0.0^{\mathrm{a}}$ & $24.2 \pm 0.6^{\mathrm{a}}$ & $2.7 \pm 0.3^{\mathrm{a}}$ & $1.6 \pm 0.3^{\mathrm{b}}$ \\
2000 & $88 \pm 8.7^{\mathrm{a}}$ & $21.3 \pm 2.3^{\mathrm{a}}$ & $2.7 \pm 0.6^{\mathrm{a}}$ & $1.3 \pm 0.3^{\mathrm{b}}$ \\
3000 & $73.3 \pm 23.6^{\mathrm{b}}$ & $16.4 \pm 4.8^{\mathrm{b}}$ & $2.8 \pm 0.3^{\mathrm{a}}$ & $1.5 \pm 0.3^{\mathrm{b}}$ \\
4000 & $33.3 \pm 13.3^{\mathrm{c}}$ & $7.7 \pm 3.3^{\mathrm{c}}$ & $2.9 \pm 0.1^{\mathrm{a}}$ & $1.4 \pm 0.1^{\mathrm{b}}$ \\
\hline
\end{tabular}

Values are mean $\pm S D(n=3)$. Different letters within a column indicate that means are significantly different among salinity treatments $(p<0.05)$.

Table 4. Seed germination and growth parameters of Calotropis procera and Trigonella foenum-vulgare seedlings germinated at $25^{\circ} \mathrm{C}$.

\begin{tabular}{|c|c|c|c|c|}
\hline \multirow{2}{*}{ Treatment } & \multirow{2}{*}{ Calotropis } & & & \multirow{2}{*}{ Trigonella } \\
\hline & & \multicolumn{2}{|c|}{ Calotropis Trigonella } & \\
\hline Germination (\%) & $100^{a}$ & $34^{b}$ & $32^{c}$ & $52.5^{c}$ \\
\hline Shoot length (cm) & $0.5 \pm 0.2^{a}$ & $1.3 \pm 0.5^{\mathrm{b}}$ & $2.2 \pm 1.5^{c}$ & $6.0 \pm 0.5^{d}$ \\
\hline Root length (cm) & $1.1 \pm 0.6^{a}$ & $1.9 \pm 0.5^{\mathrm{ac}}$ & $1.8 \pm 0.4^{c}$ & $2.3 \pm 0.8^{c}$ \\
\hline
\end{tabular}

Values are mean $\pm S D(n=3)$. Different letters indicate that means are significantly different among treatments $(p<0.05)$.

(Boutraa, 2010). Our investigation showed that seeds collected only from mature fruits were viable, while premature seeds failed to germinate. The high viability of seeds gives opportunity to the plant to establish whenever it finds the proper habitats. Francis (2003) reported that seedlings of $C$. procera often grow in large numbers after rainy periods, but only a few survive the first season.

Light is an important factor in seed germination because in many seeds, phytochrome-mediated responses play a critical role in determining the time of germination and thus become a crucial part of the evolutionary strategy to impose conditional dormancy to protect seedlings from environmental extremes (Gula et al., 2013). Pronounced inhibition of germination was observed in the seeds of giant milkweed exposed to light conditions, while the highest germination percentages were obtained in dark. This means that without complete burial in the ground, the seeds of Calotrope could not germinate and establish in its habitats. This helps in explaining why Calotrope populations distribute as single fewer individuals in the field (El-Middany, 2014). It was reported that seeds of only few shrubs, including Artemisia monosperma, Artemisia ordosica, Artemisia sphaerocephala (Huang and Gutterman, 1999; 2000), are highly sensitive to light for germination. However, similar to several darkgerminating seeds, for example, Amaranthus caudatus, Cucumis sativus, and several cultivars of Lactuca sativa, germination of mature non-dormant seeds of $C$. procera was inhibited by intermittent infra-red light, though more frequent daily exposures were required (Sharma and Amritphale, 2008). Such retardation of germination by exposure to light has been reported to occur in the seeds of many other plants (Baskin and Baskin, 1998). In addition, the mechanism behind this light inhibition is somehow related to red/infra-red light, which is operative in many seeds or due to the accumulation of some toxic products of respiration (Thornton, 1935).

Temperature can affect the percentage and rate of germination through its effects on loss of dormancy and the germination process itself (Roberts, 1988). Reduced temperatures and critical high temperature would be expected to retard the metabolic rate to the point where pathways essential for the onset of germination would cease to operate (Verma et al., 2010; Kumar et al., 2011). The influence of temperature on germination in this study indicated that seeds of $C$. procera have a narrow range of temperature to germinate. Irrespective to the time of harvesting, temperature of 25 and $30^{\circ} \mathrm{C}$ seemed to be optimum for seed germination of giant milkweed seeds. According to Baskin and Baskin (1998), temperature requirements for shrubs in hot semi-deserts and deserts to achieve 60 to $100 \%$ germination range from 15 to $35^{\circ} \mathrm{C}$, with temperatures of about 20 to $25^{\circ} \mathrm{C}$ being suitable for most species.

The germination percentage was declined by increasing or decreasing the temperature more than the optimum. It looks that seeds collected from EPOD and LPOD fruits had more germination success than the predehiscent ones. Nevertheless, the present study furnishes the information regarding the relation between temperature regime and seed germination, taking only the time of harvesting into considerations while other 
factors are constant. The present study indicates that giant milkweed seeds failed to germinate at $15^{\circ} \mathrm{C}$ and attained lower percentages at both 20 and $35^{\circ} \mathrm{C}$ than at 25 and $30^{\circ} \mathrm{C}$. We think that the germination capacity of these seeds may be altered significantly if they are exposed to high-temperature conditions during germination. In summer, temperature is usually $35^{\circ} \mathrm{C}$ or higher and the soil temperature may be in many places, where the species is distributed, higher than air temperature (for example, in exposed sandy soil). It seems to be a critical period up to which the embryo can withstand the high temperature conditions and the germination capacity of the seeds may fall with longer duration before rain. It was reported that many seeds of shrubs, succulents, and forbs germinated in the arid lands following rains in autumn and early winter, when temperatures were decreased (Huang et al., 2003). It is apparent from the results of the present study that $C$. procera has a relative salt tolerance during its germination stages, but this tolerance is low under high $\mathrm{NaCl}$ concentrations. According to Francis (2003) and Orwa et al. (2009), giant milkweed is known to be a drought-resistant, salt-tolerant species and it is capable of surviving in a range of soil types, including alkaline and saline soils. This is obvious in the distribution of this species in the habitats close to River Nile and its adjacent desert areas, which are characterized by relative low salt content compared to salt treatments in the present study (El-Midany, 2014). Moreover, the inhibitory effects of $\mathrm{NaCl}$ on seed germination could be due to its direct effect on the growth of the embryo (Al-Khateeb, 2006).

In the life cycle of a plant, seeds have the highest resistance to extreme environmental stresses, whereas seedlings are most susceptible, and this is especially true for desert species (Gutterman, 1993). Therefore, successful establishment of a plant population is dependent on the adaptive aspects of seed germination and of early seedling growth (Qu et al., 2008). The shoot length of $C$. procera seedlings was not greatly affected by salinity variations while the root length was greatly affected in saline compared to the control treatment. Similar to Poljakoff-Mayber et al. (1994), the most influential effect of salt was on the root, which may delimit the germination success and establishment of the seeds in their habitats. They found that the elongation of the embryonic axis of Kosteletzkya virginica was strongly inhibited by high levels of $\mathrm{NaCl}$ in irrigation solutions. Alternatively, $\mathrm{NaCl}$ may also increase the osmotic potential of the media causing inhibitory effects on seed imbibitions (Poljakoff-Mayber et al., 1994; Al-Khateeb, 2006). Salt tolerance during germination and early seedling stages is critical for the establishment of plants which can grow in saline soil (Perez et al., 1998; Al-Khateeb, 2006).

The germination of $C$. procera seeds was significantly affected when germinated with $T$. foenum-vulgare with the reduction of germination from 100 to $34 \%$, while the latter plant was not affected. C. procera had inhibitory effect on germination rate and seedling length of wheat, radish and canola (Abdel-Farid et al., 2013). It plays an important role in the formation of its natural habitats as it contains the allelochemical compounds that enable the plant to compete with other species (Al-Zahrani and Al-Robai, 2007).

\section{Conclusions}

Our study indicates that direct light and high salinity inhibit the germination of $C$. procera seeds. The period after seed dispersal (in summer months) seems very critical for the plant either due to absence of rain in the study area or high temperature $\left(\geq 35^{\circ} \mathrm{C}\right)$ which inhibits seed germination. Temperatures between 25 and $30^{\circ} \mathrm{C}$ are optimum for seed germination. C. procera has a relative salt tolerance during the germination stages but this tolerance was reduced under high salinity. Plant roots were more sensitive to salinity than shoot system during germination. It seems that high temperature, direct light conditions and high salinity are limiting factors for the establishment of its seeds. Only fully mature seeds can germinate successfully regardless of the harvesting date.

\section{REFERENCES}

Abdel-Farid I, El-Sayed M, Mohamed E (2013). Allelopathic potential of Calotropis procera and Morettia philaeana. Int. J. Agric. Biol. 15:130134.

Al-Khateeb SA (2006). Effect of salinity and temperature on germination, growth and ion relations of Panicum turgidum Forssk. Bioresour. Technol. 97:292-298.

Al-Zahrani HS, Al-Robai SA (2007). Allelopathic effect of Calotropis procera leaves extract on seed germination of some plants. J. King Abdollah Univ. Sci. 19:115-126.

Angevine MW, Chabot BF (1979). Seed germination syndromes in higher plants. In: Solbrig OT, Jain S, Johnson B, Raven PH (Eds.), Topics in plant population biology. Columbia University Press, New York pp.188-206.

Baskin CC, Baskin JM (1998). Seeds: ecology, biogeography, and evolution of dormancy and germination. Academic Press, San Diego.

Boutraa T (2010). Growth performance and biomass partitioning of the desert shrub Calotropis procera under water stress conditions. Res. J. Agric. Biol. Sci. 6:20-26.

El-Middany MM (2014). Population dynamics of Calotropis procera (Ait.) R. Br. in Cairo province. M.Sc. Thesis. Helwan University, Cairo, Egypt.

Francis JK (2003). Calotropis procera. U.S. Department of Agriculture, Forest Service, International Institute of Tropical Forestry, Puerto Rico.

Frosi G, Oliveira MT, Almeida-Cortez J, Santos MJ (2012). Ecophysiological performance of Calotropis procera: an exotic and evergreen species in Caatinga, Brazilian semi-arid. Acta Physiol. Plant 35:335-344.

Gula B, Ansari R, Flowers TJ, Khan MA (2013). Germination strategies of halophyte seeds under salinity. Environ. Exp. Bot. 92:4-18.

Gutterman Y (1993). Seed germination in desert plants. Adaptations of desert organisms. Springer-Verlag, Berlin.

Huang ZY, Gutterman Y (1999). Influences of environments factors on achene germination of Artemisia sphaerocephala, a dominant semishrub occurring in the sandy desert areas of Northwest China. South Afr. J. Bot. 65:187-196.

Huang ZY, Gutterman Y (2000). Comparison of germination strategies of Artemisia ordosica with its two congeners from deserts of China and Israel. Acta Bot. Sin. 42:71-80. 
Huanga Z, Zhanga X, Zhengb G, Gutterman Y (2003). Influence of light, temperature, salinity and storage on seed germination of Haloxylon ammodendron. J. Arid Environ. 55: 453-464.

ISTA (1985). International rules for seed testing. Seed Sci. Tech. 13: 299-355.

Khan MA, Gulzar S (2003). Light, salinity and temperature effects on the seed germination of perennial grasses. Am. J. Bot. 90:131-134.

Khan R, Shahzad S, Choudhary MI, Khan SA, Ahmad A (2007). Biodiversity of the endophytic fungi isolated from Calotropis procera (Ait.) R. Br. Pak J. Bot. 39:2233-2239.

Kumar B, Verma SK, Singh HP (2011). Effect of temperature on seed germination parameters in Kalmegh (Andrographis paniculata Wall. ex Nees.). Indust. Crops Prod. 34:1241-1244.

Lottermoser BG (2011). Colonization of the rehabilitated Mary Kathleen uranium mine site (Australia) by Calotropis procera: Toxicity risk to grazing animals. J. Geochem. Explor. 111:39-46.

Magalhães HIF, Ferreira PMP, Moura ES, Torres MR, Alves APNN, Pessoa ODL, Costa-Lotufo LV, Moraes MO, Pessoa C (2010). In vitro and in vivo anti-proliferative activity of Calotropis procera stem extracts. Ann. Acad. Bras. Ciên. 82: 407-416.

Meyer SE, Monsen SB, McArthur ED (1990). Germination response of Artemisia tridentata (Asteraceae) to light and chill, patterns of between-population variation. Bot. Gaz. 151:176-183.

Mueen AKK, Rana AC, Dixit VK (2005). Calotropis species (Ascelpediaceae), a comprehensive review. Pharmacognosy Magazine 1:48-52.

Noe G, Zedler BJB (2000). Different effects of four abiotic factors on the germination of salt marsh annuals. Am. J. Bot. 87: 1679-1692.

Oliveira S, Negreiros D, Fernandes GW et al. (2009). Seedling growth of the invader Calotropis procera in ironstone rupestrian field and seasonally dry forest soils. Neotrop. Biol. Conserv. 4: 69-76.

Orwa C, Mutua A, Kindt R, Jamnadass R, Simons A (2009). Calotropis procera. Agroforestree Database: A Tree Reference and Selection Guide. World Agroforestry Centre, Kenya.

Parsons WT, Cuthbertson EG (2001). Noxious weeds of Australia. 2nd ed. CSIRO Publishing, Melborn, $712 \mathrm{p}$.

Perez T, Moreno C, Seffino GL, Grunber A, Zenoff B (1998). Salinity effects on the early development stages of Panicum coloratum: Cultivar differences. Grass Forage Sci. 53: 270-278.

Perumal SA, Varghese B, Govender P, Ramdhani S, Berjak P (2014). Effects of elevated temperature on germination and effects of elevated temperatures on germination and subsequent seedling vigour in recalcitrant Trichilia emetica seeds. South Afr. J. Bot. 90: 153-162.

Poljakoff-Mayber A, Somers GF, Werker E, Gallagher JL (1994). Seeds of Kosteletzkya virginica (Malvaceae): Their structure, germination and salt tolerance. II. Germination and salt tolerance. Am. J. Bot. 8: 54-59.
Qu X, Huang Z, Baskin JM, Baskin CC (2008). Effect of temperature, light and salinity on seed germination and radicle growth of the geographically widespread halophyte shrub Halocnemum strobilaceum. Ann. Bot. (London) 101: 293-299.

Redondo-Gómez S, Mateos-Naranjo LE, Cambrollé J, Luque T, Figueroa ME, Davy AJ (2008). Carry-over of differential salt tolerance in plants grown from dimorphic seeds of Suaeda splendens. Ann Bot. 102: 103-112.

Roberts EH (1988). Temperature and seed germination. In: Long SP, Woodward FL. (Eds.), plants and temperature. Symposia of the Society of Experimental Biology. Company of Biologists Ltd., Cambridge. 42:109-132.

Sen DN, Chawan DD, Chatterji UN (1968). Diversity in germination of seeds in Calotropis procera R. Bm population. Osterr. Bot. Z. 115:617.

Sharma S, Amritphale D (2008). Light environment in pre- and postdehiscent fruits affects seed germination in Calotropis procera. Env. Exp. Bot. 62: 45-53.

SPSS (2006). SPSS Base 15.0 User's Guide. SPSS Inc., Chicago, USA.

Tezara W, Colombo R, Coronel I, Marín O (2011). Water relations and photosynthetic capacity of two species of Calotropis in a tropical semi-arid ecosystem. Ann. Bot. 107: 397-405.

Thompson PA (1973). Seed germination in relation to ecological and geographical distribution. In: Heywood VA (Eds.): Taxonomy and Ecology. Academic Press, London 93-119.

Thornton NC (1935). Factors influencing germination and development of dormancy in cockle-bur seeds. Contr. Boyce Thompson Inst. 7: 477-496.

Verma SK, Kumar B, Ram G, Singh HP, Lal RK (2010). Varietal effect on germination parameter at controlled and uncontrolled temperature in Palmarosa (Cymbopogon martinii). Ind. Crops Prod. 32: 696-699.

Washitani I, Masuda M (1990). A comparative study of the germination characteristics of seeds from a moist tall grassland community. Funct. Ecol. 4: 543-557.

Wei Y, Bai Y, Henderson DC (2009). Critical conditions for successful regeneration of an endangered annual plant, Cryptantha minima: A modeling approach. J. Arid. Environ. 73:872-875. 